\title{
What should the citizen know about 'science'?
}

\author{
Jeremy Hugh Baron FRCP FRCS
}

J R Soc Med 2003;96:509-511

In a world dominated by science and technology, every citizen requires some grasp of the principles of science. How, otherwise, are non-scientists to assess the information that bombards them? In particular, they need to understand that every scientific 'truth' is subject to correction or modification.

In the early nineteenth century there was in some countries considerable unease about the public's ignorance of science. In 1825 Sweden set up a committee to reform schools and universities. It reported in 1829 , when the great chemist Berzelius claimed 'The literary education given to the generation that now leads in public affairs, classical languages, belles lettres and history, has resulted in nine-tenths of our civil servants and pastors not being able to explain what causes the moon to wax or wane and how it happens that the mercury rises in the barometer'. ${ }^{1} \mathrm{He}$ persuaded his country to introduce science into schools. Here I look at public knowledge as revealed by surveys in the USA and the UK.

\section{USA}

In the USA, the National Science Foundation is required to send the President a biennial report on science and engineering indicators. Americans are certainly interested in science, and are beginning to understand it better. The 2001 survey $^{2}$ of 1574 adults found $66 \%$ interested in new discoveries in medicine, $50 \%$ in science and the environment and $46 \%$ in technologies and inventions. Half had some idea of probability and how experiments are conducted; rather fewer understood what it meant to study something scientifically. In $200122 \%$ could define a molecule $(1976<10 \%)$, though not how its size compared with that of an atom or a cell. In $200145 \%$ had a minimal understanding of DNA $(1976<20 \%) .75 \%$ knew that the earth goes round the sun once a year and that light travels faster than sound. Half believed that antibiotics kill viruses and that the earliest humans lived at the same time as dinosaurs. Yet Americans increasingly hold outlandish pseudoscientific beliefs. A poll in 2002 found that half

Division of Gastroenterology, Mount Sinai School of Medicine, New York, 10029-6574, USA

Correspondence to: 21C Randolph Crescent, London W9 1DP, UK E-mail: hughbaron@aol.com favoured creationism and believed God made humans in the last 10000 years. ${ }^{3}$ More than half stated that people had been contacted recently by creatures elsewhere in the universe, and that humans had been abducted by these aliens. Astrology was thought by $41 \%$ of Americans to be at least somewhat scientific, and $60 \%$ believed in psychic power. Between 1990 and 1997 public expenditure on 'alternative' therapies more than doubled. Obviously few of us are consistently rational. Even many of the best educated avoid walking under ladders, buy tickets from the National Lottery or purchase remedies so dilute that they contain no molecule of the substance on the label.

What causes such ignorance? Americans learn about science mainly from TV (44\%) and from newspapers, the internet, radio, friends and books. In 1980 more than half of Americans (57\%) were still reading a newspaper. By 1999 this had fallen to only $41 \%$, yet each day $63 \%$ watched at least an hour of news. The average American watched more than 4 hours of TV each day; young Americans spent 900 hours each year in school and 1023 hours watching TV. ${ }^{4}$

\section{UK}

The British Association for the Advancement of Science (BAAS) was established in 1831 and one of its aims was to make the public aware of the ever-increasing importance of science. The Clarendon Royal Commission of 1861-4 was set up after T H Huxley and others campaigned for science teaching in schools (Eton introduced arithmetic only in 1836). ${ }^{5}$ This proposal was opposed by both Lords and Commons so that the 1868 Public Schools Act did not compel science teaching. The British Science Guild was founded in 1905 also with specific objectives, but after some early success faded and merged in 1936 into the BAAS. ${ }^{6}$

The 1985 Royal Society document The Public Understanding of Science, ${ }^{7}$ later summarized by its chairman Walter Bodmer in two Bernal lectures, ${ }^{8}$ defined science as 'the systematic investigation of the natural world and the practical application of knowledge derived from such investigation'. The public was considered to understand neither 'the principles nor the limitations of scientific method, causality, probability, quantitative aspects, and the intrinsic variability of natural phenomena. Scientific thinking included observing, pattern 
seeking, explaining, experimenting, communication, applying .... However in this 1985 report the term hypothesis was not used. Because 'few [surveys] are devoted to assessing the understanding of science and technology, the Royal Society recommended the Economic and Social Research Council to sponsor such surveys. ${ }^{9}$

In 1988 38\% of British respondents declared they were very interested in new discoveries in science and 49\% in those in medicine, but only $10 \%$ and $9 \%$ considered themselves well informed in these areas. Indeed only 3\% named theory construction and 10\% experimental method as processes of scientific enquiry. The sun was believed by $30 \%$ to rotate round the earth. The House of Lords Select Committee's Science and Society document of $2000^{10} \mathrm{did}$ emphasize 'the testing of hypotheses by experiment', but was primarily concerned with the public attitudes to science, as have been other publications such as the Wellcome Trust/Office of Science and Technology Science and the Public of 2000. ${ }^{11}$

Soon after publication of its 1985 document, the Royal Society with BAAS and the Royal Institution founded the Committee on the Public Understanding of Science (COPUS) 'to interpret these scientific advances and make them more accessible to non-scientists.' COPUS was active over several years in trying to assess and improve the public's understanding of science. Unfortunately the complexity of its sponsorship by three very different kinds of body caused COPUS to experience operational difficulties that led to its being shut down in December 2002.

\section{What is science?}

The current Encyclopaedia Britannica entry on the philosophy of science takes up 55 columns and gives 3 columns of citations. My own early training in the 1940s and 1950s emphasized the scientific basis for the theory and practice of medicine including biometry and practical statistics. Many of my teachers cited Kelvin's 'Science is measurement', but I was not taught about testing hypotheses, let alone Karl Popper's model of falsifiability ${ }^{12}$ or the notion of predictive verification. ${ }^{13}$

The art historian Ernst Gombrich took an interest in the logic of scientific discovery: 'Scientific theories cannot result from unaided observations, because unless the scientist has a hypothesis to test it would be impossible to know which observations were relevant. Science proceeds when earlier hypotheses are refuted by the data, and awareness of this history of "conjecture and refutation" is what stimulates new hypotheses.' ${ }^{14}$ As Darwin put it, 'How odd it is that anyone should not see that all observations must be for or against some view if it is to be any service'. ${ }^{15}$ taught the meaning of 'science'. I am not aware of any UK surveys of the understanding of science by children, by undergraduate or postgraduate students of liberal arts, science or medicine, or by practising scientists or doctors. In my own tiny studies I asked for a sentence on 'science' and searched the anonymous answers for certain terms. Only 5 of 25 final year London medical students used 'experiment' one mentioned 'theory' and none mentioned 'hypothesis'. ${ }^{16}$ Just 3 out of 18 undergraduate science students in the USA used these terms. In an independent English school none of 11 girls age 16-18 studying sciences mentioned any of these terms, though 2 of the 7 taking liberal arts did use the word 'experiment'.

\section{CONCLUSIONS}

Lack of understanding of basic principles of science is not due to a quantitative scarcity of information. It is probably due to a failure to provide, from schooldays to adulthood, simple clear outlines of scientific principles that will enable all citizens, let alone politicians and journalists, to understand their world, their bodies and how decisions can be made and tested rationally. ${ }^{17}$ The core curriculum for schools could contain specific points for school-leavers to appreciate. Some could be simple statements-for example, the moon goes round the earth about every 28 days; the earth rotates every 24 hours and goes round the sun every 3651/4 days; light travels faster than sound; the earliest humans lived more than a hundred thousand years ago and evolved by natural selection from other forms of life (and long after dinosaurs); an atom contains still smaller charged constituents and a molecule contains more than one atom, sometimes hundreds; antibiotics kill bacteria, but viruses only rarely; all drugs are either useless or dangerous or both. Other points would be conceptual, such as probability, risk, the conduct of experiments and what it means to study something scientifically. Perhaps above all, if event B follows event A then B is not necessarily caused by A - that is, sequence does not imply consequence. It would be reassuring to see, in successive surveys, some evidence of a better public grasp of these matters.

\section{REFERENCES}

1 Corps JOE. Berzelius: His Life and Work. Berkeley: University of California Press, 1970:120

2 National Science Foundation. Report on Science and Technology Indicators. Arlington, VA, 2002

3 Kristen ND. God, Satan and the media. NY Times, March 4, 2003:A25

4 Talbot M. Turned on, turned out. NY Times Magazine, February 16, 2003:9-10

5 Shorter C. Public Schools and Private Education: the Clarendon Commission 1861-4 and the Public Schools Act. Manchester: Manchester University Press, 1988 
6 Macleod R. Science for imperial efficiency and social change. Reflections on the British Science Guild. Public Understanding of Science 1994;3:155-93

7 Royal Society. The Public Understanding of Science. London: Royal Society, 1985

8 Bodmer WF. The Public Understanding of Science: the Bernal Lecture. London: Royal Society, 1986

9 Durant JR, Evans GA, Thomas GP. The public understanding of science. Nature 1989;340:11-14

10 House of Lords Parliamentary Select Committee on Science and Technology. Science and Society. London: Stationery Office, 2000

11 Wellcome Trust and Office of Science and Technology. Science and the Public. London: Wellcome Trust, 2000
12 Popper KR. The Logic of Scientific Discovery (1935). London: Hutchinson, 1959

13 Ziman J. Real Science: What it Is, and What it Means. Cambridge: Cambridge University Press, 2000:226

14 Hall J. EH Gombrich, the preference for the primitive. Times Lit Suppl 18 October 2002, 3

15 Darwin C. Observation, 18 September 1861. In: Burckhart F, Browne J, Porter D, Richmond M, eds. The Correspondence of Charles Darwin. Cambridge: Cambridge University Press, 1994

16 Baron JH. Medical students and the history of medicine. $J$ R Soc Med 1996;89:728

17 McComas WF. The Nature of Science in Science Education: Rationales and Strategies. Dordrecht: Kluwer, 1998 